\title{
Miranda
}

Revue pluridisciplinaire du monde anglophone /

Multidisciplinary peer-reviewed journal on the English-

speaking world

$18 \mid 2019$

Guerre en poésie, poésie en guerre

\section{Translating Caribbean thresholds of pain from without: Hispaniola out of bounds, Hispaniola unbound?}

\author{
Laëtitia Saint-Loubert
}

\section{OpenEdition}

Journals

Electronic version

URL: http://journals.openedition.org/miranda/16164

DOI: 10.4000/miranda.16164

ISSN: 2108-6559

\section{Publisher}

Université Toulouse - Jean Jaurès

\section{Electronic reference}

Laëtitia Saint-Loubert, "Translating Caribbean thresholds of pain from without: Hispaniola out of bounds, Hispaniola unbound?", Miranda [Online], 18 | 2019, Online since 15 April 2019, connection on 16 February 2021. URL: http://journals.openedition.org/miranda/16164 ; DOl: https://doi.org/10.4000/ miranda.16164

This text was automatically generated on 16 February 2021.

\section{cc)}

Miranda is licensed under a Creative Commons Attribution-NonCommercial-NoDerivatives 4.0

International License. 


\title{
Translating Caribbean thresholds of pain from without: Hispaniola out of bounds, Hispaniola unbound?
}

\author{
Laëtitia Saint-Loubert
}

\author{
"You tell the story, and then it's retold as they \\ wish, written in words you do not understand, in \\ a language that is theirs, not yours." 1
}

1 The Caribbean has a complex history of imperial conquests and (neo)colonial interventions that have given birth to numerous art forms in the region in order to translate experiences of violence and war, as well as memories of struggle and survival. Poetry has been one of the privileged forms of expression for such accounts throughout the islands and territories of the Caribbean, but has not been the sole format retained for the poeticizing of such historical events. Two diasporic accounts, a fictitious testimonio, The Farming of Bones (henceforth TFB), by Haitian writer Edwidge Danticat, and a post-modern tale of pseudo science-fiction by Dominican author Junot Díaz, The Brief Wondrous Life of Oscar Wao (TBWLOW), narrate the 1937 Massacre which took place on the border area of Dajabón, along the Massacre River separating the Dominican Republic from Haiti. Both novels were published less than ten years ago, and therefore share a certain temporal distance from the events they depict. Both novels were also originally written in English, "in translation" as it were, as Danticat and Díaz are respectively part of the Haitian and Dominican diasporas living in the United States and have privileged a language that is not the one in which the genocide of 1937 was experienced. However, TFB and TBWLOW do not offer a poeticising of the Parsley Massacre that erases linguistic difference, let alone condemn it. On the contrary, both novels re-insert, here and there, snippets of Haitian Kreyòl and Spanish that re-create or "bring forth" the original trauma experienced in Hispaniola. Given the recent turn of events which both Díaz and Danticat have characterized as a human rights crisis in the Dominican Republic, whereby hundreds of thousands of Dominican citizens have been at risk of being stripped of their citizenship on the grounds of their supposed Haitianness or "non Dominicanness", the Afro-phobic sentiments that culminated in 
the massacre back in 1937 continue to haunt the island of Hispaniola and its everyday life. ${ }^{2}$ As such, both novels, when read alongside, offer further insight into the literary treatment of past traumas re-emerging in our contemporary societies.

In this article, I suggest that TFB and TBWLOW can be read as sites of a multilingual poiesis or creation ${ }^{3}$ that manifests itself in the form of a writing in translation to potentially open up spaces of recovery from and re-membering of Hispaniola's traumatic past. Translation will thus be primarily understood as a strategy of displacement (as both novels are written mostly in English and aimed primarily at global, not necessarily Caribbean-restricted audiences), as well as of deferment (as both narratives are told in hindsight). Translation is therefore a space of poetic expression that is located outside the bounds of the original site of conflict, in order to potentially break down its geographical as well as its ideological borders. It will also be understood as a non-transparent linguistic transfer that accepts and renders the presence of untranslatables as traces of the experience of trauma to open up possibilities of restoration. The Caribbean re-enactment of the biblical Shibboleth described by Danticat in TFB inscribes her testimonial within a universal intertext of racial discrimination and death based on linguistic profiling. ${ }^{4}$ In the context of Hispaniola, this "rewriting" of the Shibboleth has come to be known as the Parsley Massacre, $E l$ Corte, Kout Kouto or the Dominican Vespers, ${ }^{5}$ a traumatic event that I will analyse as one particular instance of suffering located in a series of otherwise horrendous events, suggesting a ripple effect of sorts whereby linguistic difference and language have time and again been used as a violent, if not an altogether lethal instrument of assimilation and repression in the Caribbean. Yet, when examining both texts from the angle of their temporal and spatial disjointedness, a "syncopated temporality" emerges (Gilroy) in which chronological time is disrupted and marginalised histories can be revisited and possibly re-membered. A sense of Unheimlichkeit or the feeling of something

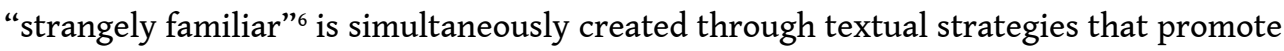
non-translation - through the refusal of unproblematized equivalencies - whilst aiming towards a decentred re-assessment of the Parsley Massacre. Ultimately, then, the survivor's testimonial bears the stamp of a linguistic difference that echoes past traumas but also paves the way for the building of a transcultural, pan-Caribbean memory, allowing a re-farming (or re-affirming) of bones through a writing in translation that rejects transparency and opts instead for positing the unintelligibility of the world as a Caribbean condition in the face of cultural amnesia.

\section{Translation and Shibboleth}

3 In 1937, Afro-phobic, anti-Haitian dictator Trujillo ordered the massacre of Haitian labourers (braceros) in the border area of the Dominican Republic, an event known as the "Parsley Massacre" or "El Corte", which saw the death of tens of thousands of Haitians and Dominicans alike. ${ }^{7}$ To distinguish Haitians from Dominicans, a litmus test was performed on the people attempting to flee and cross the border into Haiti: a sprig of parsley was held up to the fugitives' faces and when asked what it was, those who were able to pronounce correctly the Spanish word perejil (parsley) were assumed to be Dominicans, hence spared death. It comes with little surprise then that parsley is used as a leitmotiv throughout TFB: as Amabelle's (the main character's) narrative progresses, the reader is made aware of several possible explanations as to the reason 
why the word perejil, out of all expressions at hand, was chosen as a means of weeding out the people presumed of Haitian descent from the border area of Dajabón in the Dominican Republic. Those who were unable to pronounce the Spanish jota correctly were assumed to be Haitians and immediately killed, as Danticat depicts throughout her novel, and Díaz hints at in seemingly anecdotal fashion throughout the numerous footnotes he adds to TBWLOW. ${ }^{8}$ However, Danticat's narrative principally differs from Díaz's in its omnipresent focus on parsley which she intrinsically links with the 1937 massacre. Parsley is in fact seen as a pharmakon in Danticat's novel, providing both the cure to an ailment-a key feature of the plot, as Amabelle's late parents were both healers and drowned in the river Massacre while attempting to cross the border to get pots and medicinal herbs-and functioning as the poison itself. ${ }^{9}$ The novel thus oscillates in its various attempts at pinpointing the exact origin of this choice of word, as is shown by the uncertain nature of the rumours spreading on the association of parsley and death ${ }^{10}$ and later on which emerges again when the narrator witnesses one of her friend's death, in which parsley is unequivocally associated with "cleansing", a term that implies all the ambiguity of the pharmakon:

[...] But parsley? Was it because it was so used, so commonplace, so abundantly at hand that everyone who desired a sprig could find one? We used parsley for our food, our teas, our baths, to cleanse our insides as well as our outsides. Perhaps the Generalissimo in some larger order was trying to do the same for his country. (Danticat 203)

The French translation, however, lifts some of the ambiguity present in the original 'cleansing', opting for a term that suggests bodily hygiene rather than large-scale murder: 'Nous utilisions le persil pour nous nourrir, pour nos tisanes, nos bains, pour nous laver à l'extérieur autant qu'à l'intérieur'. ${ }^{11}$ The narrator's inability to find coherence behind the dictator's senseless actions, hinting, at the same time, at the possibility of some grander design of which she remains unaware but is highly sceptical, finds an echo, later, with Amabelle's employer Señora Valencia and her own interpretation of the parsley test:

Your people did not trill their $r$ the way we do, or pronounce the jota. 'You can never hide as long as there is parsley nearby,' the Generalissimo is believed to have said. On this island you walk too far and people speak a different language. Their own words reveal who belongs to what side. (Danticat 304)

5 This extract illustrates how linguistic difference served as an instrument of repression and even death in everyday life under Trujillo's regime, whilst in Díaz's text this particular event is also linked to repeated acts of violence throughout the Americas that re-connect the demise of indigenous peoples from the Caribbean with that of Native Americans, for example, thereby questioning the United States' own involvement in negotiating its History. ${ }^{12}$ The following footnoted mention of perejil in TBWLOW further complicates instances of involvement and resistance in the face of ethnic cleansing, as is suggested by acts of blind acquiescence and laissez-faire on the part of civilians who become accomplice-witnesses:

As a general practice Abelard tried his best not to think about El Jefe at all, followed sort of the Tao of Dictator Avoidance, which was ironic considering that Abelard was unmatched in maintaining the outward appearance of the enthusiastic Trujillista. $^{24}$

But what was even more ironic was that Abelard had a reputation for being able to keep his head down during the worst of the regime's madness - for unseeing, as it were. In 1937, for example, while the Friends of the Dominican Republic were 
perejiling Haitians and Haitian-Dominicans and Haitian-looking Dominicans to death, while genocide was, in fact, in the making, Abelard kept his head, eyes and nose safely tucked into his books [...]. Acted like it was any other day. (Díaz, 214-215)

6 Abelard is a fictional character created by Díaz that allows the author to connect historical facts and figures with the "hero's" own family, as Abelard is Oscar's grandfather. The verb "perejiling" here, coined by Díaz, left in Spanish and in a regular font in the footnote, translates onto the page the forced ingestion of parsley, whereas in Danticat's novel, it is Amabelle's body that becomes a site of trauma, as linguistic violence is made flesh and the scars of the past become visible, indelible even: "Now my flesh was simply a map of scars and bruises, a marred testament." (Danticat, 225)

\section{From thresholds of pain to thresholds of recovery: a "re-farming of bones"}

7 The presence of linguistic difference and language contact in both novels corresponds to an act of translation that renders a certain "cultural authenticity" by using here and there snippets of languages supposed to express unfiltered experiences of trauma (Haitian Kreyòl and Spanish in the case of Danticat and mostly Spanglish or Dominican Spanish in the case of Díaz), whilst addressing global audiences in English. To a certain extent, linguistic difference could be interpreted as a counterpoint to the lacunae often encountered in trauma studies as the consequence of the impropriety of language to authentically render emotions such as pain, grief or sadness into actual words. In fact, both Danticat and Díaz have recourse, at times, to strategies invoking lacunae ${ }^{13}$ using dashes, ellipses or typographical blanks for example, but also offer personal reconfigurations of language. Díaz, for one, proposes an explicitly provocative nontransparent translation, ${ }^{14}$ whilst Danticat offers a palimpsestic type of translation that suggests the presence of layers of interstitial inter-linguistic meaning and recalls, to a certain extent, Venuti's concept of the "remainder" in translation. ${ }^{15}$ Although her novel was written in English, its language retains layers of Kreyòl, as is exemplified by its very title, which corresponds to a loose contextualization of "travay tè pou zo" in kreyòl, explained as "the farming of bones" in the novel ${ }^{16}$ (Danticat, 55). By retaining the intrinsic violence present in the Kreyòl proverb in the title to her novel, Danticat illustrates what Paul Bandia has referred to as "implicature" in his study of African proverbs translated for Western audiences in Translation as Reparation:

Proverbs are by nature dependent upon implicature as a communicative strategy. The writer as translator faces the choice of whether to repress this implicature by compensating for it in the translating language (either through footnotes or by incorporating supplementary material in the translation) or to retain the remainder, that peculiar aspect of the proverb which eludes assimilation or domestication by the hegemonic colonial language. (Bandia, 86)

Her translation into English of the Haitian proverb thus preserves the essence of the original image and its connotations of violence and possible death, while eluding complete assimilation when carried across in English, as the title remains at first enigmatic. Conversely, the French translation has opted for a more transparent title, $L a$ Récolte douce des larmes (transl. by Jacques Chabert, Grasset: Paris, 1999) which conveys a certain trace of suffering, but possibly associates it with a misleading sense of nostalgia absent from the original saying, while toning down the horror at the heart of the 
massacre that is suggested with the bones. ${ }^{17}$ Thus, by opting for translations of the trauma of 1937 that do not present transparent, ready-made equivalents of the massacre but ground its origins in linguistic difference, Danticat and Díaz offer modes of reading Caribbean realities that are centred around a poiesis where the scars of the past turn into highly visible, no longer seamless sutures of intergenerational wounds that have yet to be healed. It could even be argued that translation, understood both as linguistic transfer as well as geographical displacement here (writing outside Hispaniola, in English mostly), offers a valid space of contestation for heretofore silenced or traumatised voices, provided that the language of rendition manages to avoid the pitfalls of mainstream market consumption when targeting global audiences. This would entail giving in to what Elena Machado Sáez refers to as an "effortless and uncomplicated" process of absorption in her study of Market Aesthetics and the promotion of postcolonial ethics ${ }^{18}$, whereby translation could run the risk of commodifying ethnic or exotic literatures, unless it is guided by strategies of polyphonic decentring.

9 In TFB, the Haitian cane workers, this cheap labour force called "braceros" in the Dominican Republic, perhaps embody best the deeply ingrained sense of uprooting and marginalization that Caribbean individuals may experience in the region. As Sebastien, one of the cane workers, observes, "[t]hey say we are the crud at the bottom of the pot. They say some people don't belong anywhere and that's us. I say we are a group of vwayajè, wayfarers." (Danticat, 56) By displacing the disgrace associated with his people ("crud at the bottom of the pot") and translating it into vwayaje, a term that brings to mind pilgrims and pioneers alike, Sebastien transforms the notion of Unheimlichkeit (unhomeliness) into a powerful force that turns Haitian outcasts into potential harbingers of change..$^{19}$ In a Haitian context, the uncanny recalls Alejo Carpentier's real maravilloso, which he introduced in his prologue to El reino de este mundo, in which he depicts the Haitian Revolution. Although Carpentier does not limit lo real maravilloso to Haiti, but rather applies it to the Americas at large, he nonetheless grounds the extraordinary and the uncanny in the reality of Haiti as he experienced it, what he sums up as "lo maravilloso [que] fluya libremente de una realidad estrictamente seguida en todos sus detalles" ${ }^{20}$. The fact that in Danticat's novel Kreyòl is the language chosen to carry across this positive and somehow elevating characteristic further stresses the importance of the vernacular as an instrument of resistance to assimilation here. In fact, Unheimlichkeit or aiming towards a sense of unfamiliarity and the bizarre (or uncanny) where it applies to translation could further be interpreted, in both novels, as part of a strategy consisting in destabilizing the normative, and to a certain extent, repressive nature of a monolinguistic approach. As Edwin Gentzler explains in his introduction to Translation and Identity in the Americas, translation has been a powerful, far from neutral instrument in the region, and when used as a repressive tool, has been the cause of a "loss of identity and psychological trauma" (Gentzler, 3) ${ }^{21}$ It comes with no surprise then that diasporic writers Díaz and Danticat work on renegotiating the power imbalance initially present in the Caribbean, offering, each on their own terms, a refashioning of language that entails a complete turning of tables and a two-fold understanding of Unheimlichkeit: a concept that both recalls the experience of trauma linked to displacement which breeds a sense of unfamiliarity and loss, but one that also functions as a potential antidote (where the pharmakon is a cure) to assimilationist enterprises. In TBWLOW, the multiple allusions to the need of filling out the "páginas en blanco" of History-and, precisely, not its blank 
pages-partake in Díaz's strategy to both deconstruct and destabilize hegemonic discourses and try and redress this imbalance from marginal spaces and through "subaltern"22, heretofore silenced voices. His footnotes act, for instance, as digressions to the main plot and perturb the sense of familiarity the reader may have with the book object, all the more so as his numerous self-referential addenda circumvent any traditional, linear mode of reading and may be experienced as particularly unsettling, if not confusing. In Danticat's novel, this dual reading of Unheimlichkeit can be found in the chronological breaks that are interspersed with the narrator's testimony. In TFB, the main plot is clearly distinguished from what may be called dream sequences ${ }^{23}$ that appear in bold font and in which Amabelle is revisiting her past but is also trying to remember (both recall and refashion) the trauma she experienced, to "pass it on", even if only in silence:

It is perhaps the great discomfort of those trying to silence the world to discover that we have voices sealed inside our heads, voices that with each passing day, grow even louder than the clamor of the world outside.

The slaughter is the only thing that is mine enough to pass on. All I want to do is find a place to lay it down now and again, a safe nest where it will neither be scattered by the winds, nor remain forever buried beneath the sod.

I just need to lay it down sometimes. Even in the rare silence of the night, with no faces around. (Danticat, 266)

10 The present tense used in this sequence adds a sense of immediacy that confirms the impossibility of separating past and present within the space of traumatic memory. This blending of time creates a temporal disjointedness, also present in Díaz's novel. Whereas in the former, Danticat's use of the dream sequences may arguably be interpreted as an expression of the return of the repressed, in TBWLOW, Díaz plays with the notion of fukú, an untranslated Dominican Spanish expression to express the idea of a streak of bad luck, and deconstructs chronological time by going backwards and forwards in space as well as in time, recalling, somehow, Kurt Vonnegut's own hero, Billy Pilgrim, who "has come unstuck in time" after witnessing the bombing of Dresden in Slaughterhouse-Five. Díaz further destabilizes his narrative by inserting sciencefiction references-a strategy he shares with Vonnegut ${ }^{24}-$, incursions that put to the test the expected sense of authenticity that the narrator-witness is supposed to be entrusted with. In fact, science-fiction allows the Unheimlich, all the unspeakable aspects pertaining to trauma, to be recounted through an unusual narrative frame which could eventually help make sense of otherwise unfathomable actions when transposed to the realm of the supernatural. ${ }^{25}$

11 Caribbean experiences are thus inscribed within a "syncopated temporality", whereby chronological time is out of synch and comes to represent discontinued and scattered, diasporic realities. ${ }^{26}$ Ultimately, then, the survivor's testimonial bears the stamp of a linguistic difference that echoes past traumas but also paves the way for the building of a transcultural memory. The choice not to translate into English expressions left in Spanish or Kreyòl corresponds to a view of translation that should not aim towards transparency, and opts instead for positing the unintelligibility of the world as a Caribbean condition which entails living in the contact zone of colonial and neocolonial encounters, whether it is somewhere in the Antilles or in diaspora. ${ }^{27}$ 


\section{Translational counterspells, transnational re- memberings}

12 The re-telling of the 1937 massacre by Caribbean writers from neighbouring islands and territories of Hispaniola allows for the creation of a transcultural memory for the region, based on archipelagic re-membering. This poiesis is two-fold; first, it consists in re-inscribing the (partially) silenced Parsley Massacre within Hispaniola's history, and, to some extent, within larger narratives of trauma. Elissa L. Lister acknowledges this gap in official discourses on Hispaniola, particularly in the Dominican Republic, where she observes a "politics of oblivion":

Les manifestations des politiques de l'oubli autour des événements de 1937 se retrouvent autant dans la pratique que dans les discours. [...] Cette absence contraste, cependant, avec l'emphase mise dans la description de l'occupation haïtienne de 1822 à 1844, dans celles des incursions des hordes haïtiennes, ainsi décrites, dans le domaine dominicain tout au long du XIXème siècle et dans la comptabilisation des prétendues batailles et guerres qu'ils ont du livrer pour arriver à les contenir. Par ailleurs, quand bien même ils essaient d'apporter des points de vue et des approches critiques ou d'offrir une certaine minutie dans le traitement d'autres sujets, les manuels et les livres d'histoire dominicaine minimisent ou occultent l'extermination; leurs auteurs deviennent ainsi, volontairement ou inconsciemment, les collaborateurs du discours institutionnalisé de la négation de l'holocauste. (Lister, 20-21)

In addition to retrieving repressed histories, the strategies of re-membering suggested here also consist in stitching back together fragments of Caribbean histories that form a mosaic-like whole, as long as they are considered from more than one site of remembrance and experience. In her collection of short-stories Encancaranublo y otros cuentos de naufragio, Ana Lydia Vega therefore transplants the original massacre, "el dia de los hechos", onto a contemporary Puerto Rican landscape, offering a re-enactment of the 1937 massacre whereby the owner of a laundromat of Haitian descent is found dead on the floor of his establishment. The story juxtaposes elements of the original setting with clear references to Puerto Rico, as can be observed in the following extract:

Fue durante la semana roja de no acordarse. El Benefactor había proclamado la muerte haitiana a todo lo largo del Masacre. La dominicanización de la frontera estaba en marcha. [...] Un brillo de armas filosas prendió el batey. A las seis de la mañana, Paula frotaba el piso con un cepillo para hacerle vomitar sangre de haitiano a las tablas sedientas.

Por eso, aquel día, Filemón Sagredo hijo, descendiente de tantos filemones matados y matones, estaba de cara en el Laundry Quisqueya de Río Piedras. (Vega, 25-26)

The initial site of ethnic cleansing, explicitly referred to in the first paragraph in expressions such as "a todo lo largo del Masacre" ("el Masacre" being the river here) or "la dominicanización estaba en marcha", is transposed to another Caribbean setting (the popular neighbourhood of Río Piedras in the metro area of San Juan, Puerto Rico), where the Haitian character, Filemón Sagredo, is found dead, victim of a homicide motivated by deep-seated feelings of hatred and racial prejudice, just like his ancestors before him. This is suggested in the last sentence of the extract by the pluralized form "filemones", derived from the character's own name and reduced here to a common noun bereft of its humanity, as the absence of capitalization indicates. This transposition onto a Puerto Rican setting invites a broader reflection on the day-to-day treatment of historically ingrained prejudices and on identity issues in the region. In 
the title story of her collection, "Encancaranublo", Vega once again suggests the potentially divisive nature of linguistic difference in the region, as she brings together a Haitian, a Dominican and a Cuban on a boat bound for the US. In the story, the Haitian and Dominican characters are pitted against each other, but the initial bilateral conflict soon leads to a broader reflection on Caribbean complex identities:

- Get those niggers down there and let the spiks take care of 'em.

Palabras que los incultos héroes no entendieron tan bien como nuestros bilingües lectores. Y tras de las cuales, los antillanos fueron cargados sin ternura hasta la cala del barco donde, entre cajas de madera y baúles mohosos, compartieron su primera mirada post naufragio : mixta de alivio y de susto sofrita en esperanzas ligeramente sancochadas.

Minutos después, el dominicano y el cubano tuvieron la grata experiencia de escuchar su lengua materna, algo maltratada pero siempre reconocible [...]. (Vega, 20)

The use of the derogatory "spiks" during this rescue scene as well as the reference to Puerto Rican Spanish being a bastardized version of Dominican or Cuban Spanish ("algo maltratada pero siempre reconocible") denounce practices of linguistic profiling that took a deadly turn during the Parsley Massacre in Hispaniola and continue, to a certain extent, to permeate everyday life and exchanges in the Caribbean. Non-domesticating translation based precisely on the re-appraisal of linguistic difference and the appreciation of polyphonic variations can, in such a light, turn into a highly disruptive tool against discriminatory discourses of homogenisation that strictly define one's identity along normative lines of language-nation/nation-language equivalency. In TFB, the refusal to say perejil and the decision to opt for the Kreyòl pèsi in the face of death, clearly inscribe the vernacular within a poetics of disruption and dignity that resists assimilation and somehow enables to reach a state of transcendence. This is evidenced in a key scene of the novel, in which Odette, a Haitian character who helps Amabelle and a group of fellow Haitians escape a theatrical re-enactment of the Shibboleth in the town square of Dajabón, later dies as the group is trying to cross the Massacre river. ${ }^{28}$ The scene ends as follows:

She had saved us at the square, so we wanted to save her too. [...] As we sat there with Odette under a canopy of trees in the middle of a grassy field, she spat up the chest full of water she had collected in the river. With her parting breath, she mouthed in Kreyòl "pèsi", not calmly and slowly as if she were asking for it at a roadside garden or open market, not questioning as if demanding of the face of Heaven the greater meaning of senseless acts, no effort to say "perejil" as if pleading for her life. [...]

The Generalissimo's mind was surely as dark as death, but if he had heard Odette's "pèsi," it might have startled him, not the tears and supplications he would have expected, no shriek from unbound fear, but a provocation, a challenge, a dare. To the devil with your world, your grass, your wind, your water, you air, your words. You ask for perejil, I give you more. (Danticat, 203, emphases mine)

The syntactic structure that repeats in both paragraphs uses the correlative conjunctions "not... but" in a pattern that seems at first incomplete, as the second element introduced by the conjunction "but" is delayed and only appears at the end of the first sentence in the second paragraph. The structure therefore stresses the character's act of resistance - her use of the Kreyòl pèsi - which becomes an act of linguistic resistance, ultimately described as "a provocation, a challenge, a dare". More generally, Díaz's use of "assertive nontranslation" (Ch'ien, 209), whereby the author inserts Spanish expressions without providing the reader with in-text translations, let 
alone elements of gloss, participates in upsetting the general flow of the main narrative in English. The Anglophone reader is thus reminded of the presence of several layers of discourse, which imply the presence of cultural and/or historical references most likely unknown to him/her. This is the case in the following example:

The scandal! Remember the time and the place: Baní in the late fifties. [...] Factor in that he'd been caught not with one of his own class (though that might have also been a problem) but with the scholarship girl, una prieta to boot. (The fucking of poor prietas was considered standard operating procedure for elites just as long as it was kept on the do-lo, what is elsewhere called the Strom Thurmond Maneuver.). (Díaz, 100)

17 Here, the interference created by the insertion of the term "prieta", which is not flanked by an English equivalent, allows Díaz to bring in the theme of interracial relationships. Although it remains to be seen whether most North-American readers would make sense of the word simply through the allusion to Strom Thurmond. To that end, the French translation of TBWLOW has similarly opted for the use of the Spanish term, while inserting a footnote to explain Díaz's reference:

Quel scandale! Rappelez-vous l'époque et le lieu: Baní à la fin des années cinquante. [...] Notez bien que s'il ne s'était pas fait attraper avec une partenaire de la même classe sociale (même si ça aurait également pu poser problème) mais avec une boursière, une prieta par-dessus le marché. (Tringler les pauvres prietas était considéré parmi l'élite comme une procédure de rigueur, du moment que ça se faisait en loucedé, cette pratique ayant même été baptisée, ailleurs, La Méthode Strom Thurmond*.)

* En référence à James Strom Thurmond, homme politique américain, membre du Parti démocrate puis du Parti républicain (qui fut gouverneur de Caroline du Sud, candidat à la présidence des Etats-Unis et sénateur). Connu pour ses positions ségrégationnistes, il avait eu une fille illégitime avec sa bonne noire-américaine. (N.d.T.) (Díaz, trans. by Laurence Viallet, 113-114; emphasis mine)

While Díaz's use of parenthetical, and to a larger extent, "liminal" comments functions as a site of diegetic interferences, ${ }^{29}$ Viallet's addition of footnotes in her translation operates on a more conventional level, whereby the translator intervenes on the text to lift possible ambiguities and ease access to the cultural subtext for a Francophone reader who may well not be familiar with it. On the contrary, when traditional acts of translation occur in TBWLOW, that is when translating directly one language (or word) into another, they can ironically turn into a double-edged sword, particularly when no longer operating within the interstices of difference and displacement. This is the case when Oscar returns to his native Dominican Republic in the last part of the novel and ultimately faces death there:

They waited respectfully for him to finish and then they said, their faces slowly disappearing in the gloom, Listen, we'll let you go if you tell us what fuego means in English.

Fire, he blurted out, unable to help himself.

Oscar - (Díaz, 322)

19 Here, translation brings about the death of the Caribbean individual, who, by providing his assassins with the English equivalent of fuego actually utters a performative cry that signs his own death warrant; perhaps, this also marks the end to fukú, the curse that Oscar's family and the island of Hispaniola were put under. TBWLOW could still be said to function as a polyphonous counterspell that wishes to re-dress the wounds of linguistic assimilation that Caribbean individuals have experienced, whether at home or when living in the diaspora, particularly as it promotes a subterranean poiesis of the 
margins, in which the inner recesses of the text and its immediate surroundings, taking the form of footnotes, parenthetical asides or ellipses, help recover hidden layers of History and heretofore silenced experiences of trauma.

Danticat chooses, for her part, an afterword that takes the form of a tribute to the victims of the 1937 massacre as well as to "those who are still toiling in the cane fields", which also bears the mark of multilingualism as a site of transcultural memory, as her acknowledgments are expressed in Kreyòl, Spanish and English. As such, both Danticat and Díaz could be said to promote acts of non-domesticating translation that disremember as much as they dis-member monolingual and national agendas.

\section{Conclusion}

Even if traces of mediation, which are overtly present in TBWLOW, yet more subtle in $T F B$, recall the necessity to beware of the agency and reliability bestowed upon any witness-narrator, such traces can also be read as fragments of a writing in translation that attempts to conjugate and accommodate local as well as transnational memories, without erasing the specificities of each site under study. Ultimately, then, when read as multilingual accounts that accept to restore multiple, mobile and intricate identities, TFB and TBWLOW promote acts of translation articulated around the visibility of linguistic difference which should be key to any study of the Caribbean literary landscape and its multilingual soundscape. Strategies of dis-location then emerge here and there in the liminal spaces of Danticat and Díaz's novels and create a space for silenced voices that re-emerge and tell their story with their own words and in their own language. ${ }^{30}$ But a "poethics" of translation also emerges that frees memories of trauma and war from the shackles of assimilation and oblivion. On a practical level, such a "poethics" would entail more transnational collaborations as well as more translational incentives across the region in order to trigger distinct, yet complementary, panCaribbean responses to shared traumas and painful memories.

\section{BIBLIOGRAPHY}

Bandia, Paul F. Translation as Reparation: Writing and Translating in Postcolonial Africa. Manchester, England; Kinderhook, N.Y.: St Jerome Publishing, 2008.

Carpentier, Alejo. El reino de este mundo. Barcelona: Seix Barral, 2012.

Chancy, Myriam J. A. Framing Silence: Revolutionary Novels by Haitian Women. New Brunswick, N.J.: Rutgers University Press, 1997.

Ch'ien, Evelyn. Weird English. Cambridge, Mass.; London: Harvard University Press, 2004.

Danticat, Edwidge. The Farming of Bones. London: Abacus, 1998.

-. La récolte douce des larmes. Trans. by Jacques Chabert. Paris : Grasset et Fasquelle, 1999. 
Derrida, Jacques. “Plato's Pharmacy." In Dissemination. Trans. and intro by Barbara Johnson. Chicago: University of Chicago Press, 1981. 61-171.

Díaz, Junot. The Brief Wondrous Life of Oscar Wao. London: Faber and Faber, 2008.

-. La brève et merveilleuse vie d'Oscar Wao. Trans. by Laurence Viallet. Paris: Plon, 2009.

Freud, Sigmund. “The Uncanny.” In Fantastic Literature: A Critical Reader. Trans. by Alix Strachey. Ed. David Sandner. Westport, CT: Praeger, 2004. 75-101.

Fumagalli, Maria Cristina. On the Edge: Writing the Border between Haiti and the Dominican Republic. Liverpool: Liverpool University Press, 2015.

Gentzler, Edwin. Translation and Identity in the Americas: New Directions in Translation Theory. New York: Routledge, 2008.

Gilroy, Paul F. The Black Atlantic. London: Verso, 1993.

Graziadei, Daniel. “Die Grenze am Massaker-Fluss: transmediale Textgräber in hispaniolischen Literaturen." In Mémoires transmédiales. Geschichte und Gedächtnis in der Karibik und ihrer Diaspora. Ed. Natascha Ueckmann and Gisela Febel. Berlin : Frank \& Timme, 2017. 243-260.

Lister, Elissa L. Le conflit haitiano-dominicain dans la literature caribéenne. Pétion-Ville : C3 Editions, 2013.

Machado Sáez, Elena. Market Aesthetics: The Purchase of the Past in Caribbean Diasporic Fiction. Charlottesville: University of Virginia Press, 2015.

McCracken, Ellen. Paratexts and Performance in the novels of Junot Díaz and Sandra Cisneros. New York: Palgrave Macmillan, 2016.

Olsen, Lance. Ellipse of Uncertainty: An Introduction to Postmodern Fantasy. Westport, CT: Greenwood Press, 1987.

Spivak, Gayatri Chakravorti. "Can the Subaltern Speak?" In Marxism and the Interpretation of Culture. Ed. Lawrence Grossberg and Cary Nelson. Urbana: University if Illinois Press; Basingstoke: Macmillan. 1988. 271-313.

Taylor, Diana. The Archive and the Repertoire: Performing Cultural Memory in the Americas. Durham and London: Duke University Press, 2003.

Vega, Ana Lydia. Encancaranublado y otros cuentos de naufragio, 7th ed. San Juan, Puerto Rico: Editorial Antillana, 2001.

Venuti, Lawrence. The Scandals of Translation. London, New York: Routledge, 1998.

\section{NOTES}

1. Words uttered by Sebastian, a victim of the Parsley Massacre. (Danticat, 246).

2. See for example Maria Cristina Fumagalli's monograph on the border area of Hispaniola: "Border dwellers and exchanges, markets, in addition to site of violence: introduction of carnets to regulate the entrance of Haitians: 'In 2012 it was established by Dominican authorities that Haitian occasional workers who live in the Haitian borderland should obtain a 'carnet' or 'identification card' valid for a year, which would give them permission to enter legally in the Dominican Republic. Two years later, however, these carnets have still not been issued and the migratory flux appears to be arbitrarily regulated, a system obviously open to abuse."' Fumagalli, 
Maria Cristina. On the Edge: Writing the Border between Haiti and the Dominican Republic. Liverpool: Liverpool University Press, 2015 (p. 8).

3. I use poeisis in the sense of creative production (from the Greek $\pi \circ \imath^{\prime} \eta \sigma \imath \varsigma$ ) as well as in the sense of craft in order to present translation not just as an art form, but as an embodied practice that produces a textual world of its own. I do not use the term in opposition to praxis, as theorized by Aristotle.

4. Danticat opens her novel with a quote (re)locating the episode of the biblical shibboleth: "Jephthah called together the men of Gilead and fought against Ephraim. The Gileadites captured the fords of the Jordan leading to Ephraim, and whenever a survivor of Ephraim said, "Let me cross over," the men of Gilead asked him, "Are you an Ephraimite?" If he replied, "No,", they said, "All right, say "Shibboleth." If he said, "Sibboleth," because he could not pronounce the word correctly, they seized and killed him at the fords of the Jordan. Forty-thousand were killed at the time." Edwidge Danticat, The Farming of Bones (London: Abacus, 1998), page unnumbered.

5. The choice of one term over the other in reference to the 1937 genocide is far from anecdotal and the act of naming cultural or historical events, as well as places or whole islands, is particularly revelatory in the Caribbean, where successive and at times simultaneously waves and forms of conquest and resistance have been echoed in the language chosen to map out geographies and temporalities alike.

6. Freud defines the uncanny as follows: "the "uncanny" is that class of the terrifying which leads back to something long known to us, once very familiar." Despite their seeming opposition, heimlich (what is familiar) and unheimlich (the uncanny or unfamiliar) are linked through their proximity to geheim (secret or withheld from others). See Freud $(76,79)$.

7. Estimates vary. See Fumagalli (140-141) and Graziadei (247).

8. The main character's life is for instance early on connected to former historical events, when Oscar's mother fortuitously compares a younger Oscar, then in his prime, to young and dashing Porfirio Rubirosa, for instance, introduced as "a part-time former model and dashing man-abouttown, Rubirosa famously married Trujillo's daughter Flor de Oro in 1932, and even though they were divorced five years later, in the Year of the Haitian Genocide, homeboy managed to remain in El Jefe's good graces throughout the regime's long run." (Díaz, 12) The capitalisation of the "Year of the Haitian Genocide" suggests a new landmark in Hispaniola's history, whereby the ethnic cleansing that took place at the border between Haiti and the DR is recognized as such. This particular occurrence partakes in a more general attempt at deconstructing nationalist bents throughout TBWLOW, especially when strategies of naming and renaming are concerned, such as in terms like "Parsley Massacre" or "Dominican Vespers", which correspond to the same historical reality but suggest different readings of the genocide.

9. "This pharmakon, this "medicine", this philter, which acts as both remedy and poison, already introduces itself into the body of the discourse with all its ambivalence. This charm, this spellbinding virtue, this power of fascination, can be - alternately or simultaneously - beneficent or maleficent." (Derrida, 70).

10. "Many had heard rumors of groups of Haitians being killed in the night because they could not manage to trill their " $r$ " and utter a throaty "j" to ask for parsley, to say perejil." (Danticat, 114)

11. Danticat, La récolte douce des larmes (220, emphasis mine).

12. In a footnote, Díaz draws a parallel between the various genocides of indigenous peoples in the Americas and situates them as the result of repeated imperial conquests which include the United States as a site of trauma, questioning at the same time official discourses and History: “23. Hatüey, in case you've forgotten, was the Taino Ho Chi Minh. When the Spaniards were committing First Genocide in the Dominican Republic, Hatüey left the Island and canoed to Cuba, looking for reinforcements, his voyage a precursor to trip Máximo Gómez would take almost three hundred years later. Casa Hatüey was named Hatüey because in Times Past it supposedly 
had been owned by a descendant of the priest who tried to baptize Hatüey right before the Spaniards burned him at the stake. (What Hatüey said on that pyre is a legend in itself: Are there white people in Heaven? Then I'd rather go to Hell.) History, however, has not been kind to Hatüey. Unless something changes ASAP he will go out like his camarada Crazy Horse. Coffled to a beer, in a country not his own." (Díaz, 212)

13. Myriam J. Chancy talks about a "culture-lacune" in her own experience as an immigrant, which she describes as "having no identity, or as having one filled with holes with what in French are referred to as lacunes" but that could be overcome, at least in her case, "by clinging to the vestiges of creole that lie dormant in [one's] mind and by preserving a sense of self in an area of [one's] consciousness that seems untranslatable." (Chancy, 16)

14. Díaz constantly calls the reader's attention to the margins of his text from where he interrogates the power dynamics at play on a diegetic level, as the flow of History and Oscar's life are interrupted by contrapuntal notes. Interestingly, though, when Díaz peppers his text with Spanish words and expressions he does not footnote them. See, for example, his allusion to the scandal associated with "prietas" in the section entitled "Translational counterspells, translational re-memberings".

15. Venuti defines the remainder as follows: "The collective force of linguistic forms that outstrips any individual's control and complicates intended meanings". (Venuti, 108)

16. The original meaning of "farm" is worth noting here, as the word was used in the sense of "banquet" or "feast" and brings to mind other Haitian writers, such as Jacques Stephen Alexis acknowledged by Danticat at the end of TFB - and his novel Général Compère Soleil in which the main character, Hilarius Hilarion, is arrested for stealing food.

17. That is as long as the adjective "douce" is understood as "sweet" and not in its ironic sense. The English translation of Philoctète's Le Peuple des Terres Mêlées invites to further reflection on editorial choices where titles are concerned, all the more so as the English translation, Massacre River (A New Directions Book, 2005, trans. by Linda Coverdale), connotes the horrors of the 1937 genocide, while the original title takes an opposite stance, focusing on harmony and cohabitation instead. Similarly, the Spanish translation of Philoctète's novel opted for Perejil, a clear reference to the meaning attributed to the word in the Dominican context. See Lister, Elissa L. Le conflit haïtiano-dominicain dans la littérature caribéenne. Pétion-Ville: C3 Éditions, 2013, p. 97.

18. Machado Sáez focuses on diasporic Caribbean authors who write historical fiction and observes: "Since Caribbean diasporic writers are positioned at the intersection of ethnic and world literatures, local and global histories, multicultural and postcolonial discourses, I argue that these authors have more in common with each other than with isolated ethnic or island literary traditions: first, their work expresses a postcolonial ethics of historical revision, and second, it struggles with the marketability of ethnicity. The novels strive to educate the mainstream readership about marginalized histories and avoid reifying any stereotypes their readers might bring to the text, chiefly the perception that ethnic writers should translate their cultures for effortless and uncomplicated market consumption." (Machado Sáez, 2)

19. The term suggests displacement and endless erring too, a condition that recalls the figure of the Wandering Jew and, to some extent, the stigma associated with Haitianness. See for example the singling out of rayanos, border dwellers of the Dominican Republic, who "owing to their proximity to Haiti [were characterized as] backward, fetishist and primitive [...]". Fumagalli (21-22).

20. Carpentier (11).

21. See the dual figure of La Malinche and her ambiguous status as translator turned traitor in historical accounts of the Americas. "During the Mexican period of nation building in the nineteenth century, Malinche was blamed for the downfall of the indigenous world." Taylor (95)

22. In reference to Gayatri Chakravorty Spivak's "Can the Subaltern Speak?". 
23. Dreams and nightmares are omnipresent in the novel. TFB opens with one such dream sequence, offset in bold, in which Amabelle is recalling a conversation she had with Sebastian about a recurring nightmare in which she kept seeing her parents drown in the river Massacre.

24. See for instance Vonnegut's references to fictitious Trafalmadorians in Slaughterhouse Five and Díaz's countless allusions to comic books, graphic novels and science fiction in TBWLOW.

25. See Lance Olsen's Ellipse of Uncertainty: An Introduction to Postmodern Fantasy, in which he explores the fantastic genre as essentially postmodern and marked by contingent meaning.

26. Gilroy talks about the "syncopated temporality - a different rhythm of living and being" that Black counter-cultures added onto modernity. (Gilroy, 281)

27. In the same vein, I have chosen to leave quotes in French and Spanish untranslated, wishing to preserve the multilingual realities of the Caribbean without flanking them with an English equivalent.

28. Danticat, 188-203. The theatricality of the passage is repeatedly stressed in the chapter, as Trujillo's presence in the cathedral of Dajabón leads to a scene of glee - the town is compared to a "carnival parade" (188) - which soon gives way to a re-enactment of the Parsley Massacre as Amabelle and her friends are assaulted and force-fed parsley by a group of young Dominican men. The simultaneity of the two performances (Trujillo's celebration and the "sacrifice" of Haitians) creates a sense of Unheimlichkeit as the cheerful rhythms and lyrics of the traditional Dominican meringue "Compadre Pedro Juan" destabilize the reader who is concomitantly witnessing a re-enactment of the massacre - or at least a prelude to it.

29. The term liminal is preferred to paratextual here for reasons similar to those underlined by Ellen McCracken, who talks of "ports of entry" whilst distancing herself from Genette's terminology in the context of Díaz's and Cisneros's works: “Several decades after Genette's classic study, the model of the portal is useful to understand the reshaping function of paratexts. These ports of entry through which we navigate before, during, and after reading the text effectively reconstitute the literary work so that it is unstable and mutating." (McCracken, 5)

30. See the epigraph opening this contribution.

\section{ABSTRACTS}

This paper focuses on The Farming of Bones, a fictitious testimonio in which Haitian author Edwidge Danticat relates the 1937 genocide perpetrated against Haitians along the River Massacre in Hispaniola and The Brief Wondrous Life of Oscar Wao, a postmodern tale revisiting Trujillo's dictatorship by Dominican author Junot Díaz. In the context of the Parsley Massacre, as the genocide came to be known, language served as an instrument of repression and death. Yet, as will be argued, a counter-poiesis of non-assimilative, multilingual translation can be observed in both novels and will be examined as a locus of re-generation. The sites of original and repeated trauma, marked by various silences, breaks, and blanks in both narratives will turn into sites of recovery, insofar as the two novels privilege acts of (re)telling and (re)membering that escape the confines of repressive, monolinguistic tendencies and promote strategies of "assertive nontranslation" instead (Ch'ien). Díaz's postmodern techniques, aimed at debunking Dominican myths whilst subverting traditional modes of writing and reading, will be studied alongside Danticat's re-enactments of the Shibboleth to discuss how their decentring strategies may help build a transcultural Caribbean memory. 
Cet article porte sur deux romans: The Farming of Bones, récit mémoriel fictif de l'auteur haïtienne Edwidge Danticat, qui retrace le parcours d'Amabelle, survivante du génocide de 1937 perpétré à l'encontre des Haïtiens le long de la rivière Massacre à Hispaniola, et The Brief Wondrous Life of Oscar Wao, récit postmoderne de Junot Díaz, auteur dominicano-américain, qui explore, notamment, la dictature de Trujillo. Dans le contexte du Massacre du Persil ("Parsley Massacre"), expression qui désigne le génocide de 1937, la langue servit d'instrument de répression et de mort pour ceux qui ne parvenaient pas à prononcer le terme perejil («persil », en espagnol) correctement. Il s'agira toutefois de montrer comment une contre-poétique de traduction non-domestiquante et hétérolingue permet de renégocier les traumatismes du passé, visibles à travers les silences, interstices et blancs émaillant les deux récits. Les romans deviennent alors lieux de recouvrement dans la mesure où ils privilégient des actes de remembrement qui tentent de dépasser des tendances monolingues normatives et encouragent au contraire des stratégies de non-traduction permettant d'aboutir à des actes de reconstructions mémorielles. Les stratégies postmodernes de Díaz et les techniques d'écriture en filigrane de Danticat, auxquelles s'ajouteront d'autres poétiques elles aussi articulées autour d'un décentrement des langues, nous amèneront enfin à nous interroger sur les possibilités de (re)construction d'une mémoire pan-caribéenne.

\section{INDEX}

Keywords: Hispaniola, translation, Shibboleth, re-membering, thresholds of pain, thresholds of recovery

Mots-clés: Hispaniola, traduction, Shibboleth, re-mémoration/re-membrement, seuils de douleur, seuils de recouvrement

\section{AUTHORS}

\section{LAËTITIA SAINT-LOUBERT}

Université de La Réunion (E.A. DIRE)

laetitia.saint-loubert@univ-reunion.fr 